\title{
African Studies in Australasia: Comparative Trends in the U.S. and Europe
}

\author{
Peter Limb \\ Emeritus, Michigan State University \\ limb@msu.edu
}

The following talk, here slightly revised and updated, was presented to the Plenary Discussion on 'African Studies in Australasia and New Zealand: The Future?' at AFSAAP Annual Conference, Adelaide, 2017, chaired by Alec Thornton. Other contributions were 'Trends in African Studies in Australia/New Zealand' by Tanya Lyons and Wanda Warlik; discussants were Tony Binns, University of Otago, and Geoffrey Hawker, Macquarie University. Further short contributions around this broad theme are welcome to editor@afsaap.org.au

\section{Introduction}

In giving some recent comparative examples of 'doing' African Studies from the U.S. and Europe, I am mindful of the quite different academic and demographic landscapes in Australia and New Zealand, let alone across African countries, particularly in terms of funding opportunities and the relative ranking of the continent in university and government priorities. However, some trends do suggest possibilities and potentials, as well as the hazard of pitfalls for us here in the Southern hemisphere to be alert to, particularly in areas such as teaching and research, conference organising, and means of outreach such as publishing and podcasts. My viewpoint is, of necessity, rather impressionistic and subjective, but given my deep involvement in the distinctively wider field of African Studies as such, as opposed to just departmental or university structures, I hope it can offer the proverbial food for thought and further reflection on what we may achieve here. After spending nearly twenty years working on Africa in Australia, I relocated to the U.S. in 2001 where I spent the next sixteen years even more intensively embedded in the theory and practice of doing African Studies.

I will be all ears to hear from you about recent trends in Australian/New Zealand African Studies, your experiences at AFSAAP conferences (the programs of which I have often studied from afar), as well as activities at your own universities or other institutions. Scholarly gatherings are a good 
place to start, and can be quite representative of African Studies in their respective locations. I attended each of the last 17 African Studies Association (ASA) annual conferences in the United States, several Canadian Association of African Studies (CAAS) conferences, and several in Europe (the biennial European Conference on African Studies (ECAS)), and gatherings in England, Scotland, France, Sweden, Germany, Holland and Switzerland), as well as meetings in various African countries. The ASA (UK) is also often substantial, if somewhat smaller in numbers than ASA and ECAS, both of which can attract ca. 1,500 speakers. Hence, there are lots to compare.

Conferences of ASA, CAAS, and ECAS each have their own distinguishing features, ranging from the very extensive parallel panels at ASA and ECAS, both of them mega-affairs, accompanied by publishers' booths teaming with new books, non-stop African films, and major keynote speakers from Africa, to the more modest, intimate meetings in Canada and European nations more akin to the scale we have here. The very diversity of these large conferences can offer ideas. We might think, for example, how we could incorporate African films in future conferences. Or African books. It was always a great joy to visit the varied publishers' booths at ASA, sometimes bedecked by book launches. The sprawling wares of the stall of the African Books Collective (ABC), which unites over 100 African publishers, invariably was hosted by manager Justin Cox (now based more conveniently for us in Auckland), accompanied by Walter Bgoya, the Tanzanian Swahili language publisher and chairperson of the $\mathrm{ABC}$ board. Walter and his then Oxford-based manager Mary Jay had attended in force at the 1999 AFSAAP conference that I co-organised with Cherry Gertzel, and our paths would cross again in the early 2000s when I facilitated their opening of a North American book distribution centre in Michigan. ABC is keen to re-engage with AFSAAP and present the wares of African publishers and scholars at our meetings. Although there can be a clash between his attendance at AFSAAP and ASA conferences, both usually held in November, last year Justin Cox sent a sizeable box of new books published across Africa, many of which were quickly snapped up by our delegates at UNSW. This year in Dunedin, he plans to be at AFSAAP in force.

Therefore, let us not forget this particular material basis of our work, whether in print or online. Just recently (in 2019), David Mickler, founding director of the Africa Research and Engagement Centre (AfREC) at the University of Western Australia (UWA) and AFSAAP have agreed to reestablish an African Studies Reading Group in Perth, an innovation introduced by AFSAAP some years ago, but now slated to 'go digital' as a 
jointly AfREC-AFSAAP supported series. With many Australian and New Zealand universities having access to extensive digital libraries of classic and new books about Africa, it will be very interesting to measure the success of this new venture, with readers attached to universities not having to pay for books as in the past. Although our libraries are chronically weak in their coverage of imprints from Africa, a representative sample of these could later be added to the mix from, for example, $\mathrm{ABC}$, as the reading groups develop.

The last year few years have seen some remarkable innovations at African studies conferences. Recently, both ASA and ECAS have experimented with live video panels beamed in to African universities. The first occasion involving UCAD, Dakar, was memorable. Some university-based African Studies centres have also experimented with this, such as at Carleton University. In a different vein, the combined German-Swiss Africanist gathering held in both Freiburg and Basel was notable not just for a beautifully illustrated evening keynote (in French) delivered by a professor coming from Benin, but also by the migration, on a train, of delegates from one city to the other for the second group of sessions. It was also distinguished for the collaboration of two different national associations, something also apparent, from time to time, in joint gatherings between ASA and CAAS, and now wonderfully coordinated right across Europe by ECAS. In this regard, AFSAAP already brings together Africanists from Australia, Aotearoa/New Zealand and the Pacific, so our founders back in 1978 thoughtfully put in place a very nice basis for cooperation across borders.

I am sure we all have vivid memories of conferences on Africa we have attended, such as this one today in the striking setting of Monarto Lion Park. I think back, for instance, to an ASA conference in San Francisco that saw some delegates move their hotel bookings to alternative, nearby accommodations in response to industrial action by the largely African American hotel workers. And mention of the Benin professor's talk brings another to mind, at Deakin University in 1990, when Norman Etherington gave a ravishing evening address on the theme of Freudian analyses of Rider Haggard's novels, complete with images of the mountains of Zululand.

Thematic and not just general conferences on Africa also take place, on a range of subjects, some focused on the work of significant scholars, trends, or anniversaries. A meeting I attended at Stirling University in Scotland in honour of Robin Law was well attended by historians, archaeologists and other specialists in West African studies. Then there are the many meetings in the U.S., Europe and across Africa within the domains of individual disciplines, such as African Languages, Literature, or Economic History, to name just a few. Australia's resources in African Studies are of course 
limited, but in the past AFSAAP too has hosted thematic conferences, and with a little imagination, funds, and coordination, can do it again if we so wish. I will return to the question of cooperation.

\section{USA}

In some ways, such as demography and traditions, Canada is a closer fit for us but I will focus more on the U.S. where, for 16 years, I was thoroughly embedded in the African Studies scene at Michigan State University (MSU), home of one of the largest, and oldest, of the roughly dozen federally funded African studies centres. I regularly attended multiple, weekly seminars on Africa, was involved in a wide range of digital, archival, and organisational matters, as well as the teaching and supervision of postgraduate students on Africa, and I helped build the vast Africana collection, one of the largest in the U.S. As I mentioned in my keynote address, the building of a large collection of African comic art at MSU attracted scholars from around the world, and facilitated my own research.

With a good number of African and Africanist postgraduates at MSU, the idea arose of a separate postgraduate conference at the university organised by, and for, students with finance from the African Studies Center (ASC), including support for students in Africa to attend and this has continued. AFSAAP too, has in the past, hosted our own postgraduate workshop the day before our conference. Since returning home, I have seen evidence of a healthy number of postgraduates across the country and so this is something to which AFSAAP might return.

Another interesting experience was helping to start and augment the 'African Activist Archive', in both print and digital manifestations, a project funded by a large U.S. Department of Education grant, which has seen many archives of the involvement of American academics and civil society with Africa over the last 50 years brought together and partially digitised. In addition, I served three cycles on the ASA's Herskovits Book Award judging committee, which decides annually the best book in African studies. (The naming of the award is currently under review following trenchant critiques of anthropologist Melville Herskovits and a decision by ASA directors to ensure that past policies of marginalization of the older tradition of African Studies based at Historically Black Colleges as well as the work of African scholars located on the continent. are not reproduced). Again, AFSAAP has its own Cherry Gertzel award for the best paper delivered by a postgraduate to the AFSAAP conference, augmented recently by the new Cherry Gertzel Bursary Award to assist female postgraduates to do research in Africa. 
I sat on the ASA Publications and Communications committee at a time of change, when the association was deciding how to diversify their journals' content (such as adding reviews of African films), how to better use the media and experiment with scholarly podcasts recorded at its conferences. MSU, with a long history of online projects on Africa from the 1990s, helped mentor ASA staff on podcasts and co-produced several episodes with leading scholars recorded at their conferences. At MSU, over the last ten years, I cohosted the 'Africa Past and Present' (afripod.aodl.org) podcast series with prominent African studies scholars, now with 125 interviews, drawing a million hits one year. I actively participated in the MSU ASC Faculty Advisory Committee on a range of matters from African language teaching, fellowships, and appointment of new directors.

In the field of publishing, I chaired the selection committee behind the African Newspapers component of the World Newspaper Archive, a collaborative if expensive venture between universities and commercial groups, which has digitized close to one million pages of African newspapers from 1800, in three phases. Simultaneously, the challenge arose of making American interests more ethically sensitive to equitable partnerships with Africans, and I was involved in the African E-Journals Project in the early 2000s that assisted several struggling African journals to first digitize, make them more viable, and get their journals into mainstream Northern baskets (Project Muse). The project was infused with ethical concern for equity and the return of Africans' cultural and intellectual heritage into their own hands. It provided useful material and technical assistance to a dozen journals in Africa, some of which were able to make the full transition to digital publishing. This interesting pilot project was the brainchild of MSU sociologist and ASC director Professor David Wiley, a progressive scholaractivist, deported from the old Rhodesia just after Terence Ranger in the 1960s. A previous ASA president, he was prominent in establishing the Association of Concerned African Scholars (whose archive I curated, and whose leadership I briefly assumed in the 2010s).

Much has thus been happening in the digital sphere of African Studies in America, unlocking enormous resources for scholars. AFSAAP too has been interested to kick-start some digital projects. Whilst Africana primary sources are limited in Australasia, we could further explore partnerships with African institutions in this regard, and in such a way as to avoid the 'missionary' or self-interested undertone of many Northern-based projects that can verge on 'digital imperialism'. One lesson I learnt was that it greatly helps to have an experienced in-house technical team as well as academics with a track record of getting grants. Even lacking grants, if such a team is in 
place and administrators on board, mainstreaming Africana as part of regular digitisation becomes easier. This is much harder in Australia, where African Studies is not high on administrative or government priorities, but where we do achieve a 'beachhead', it makes sense to build on it in ways to enhance future research and give something back to Africa.

\section{The Need for Cooperation}

In considering possible digitisation of African studies resources in Australia or analogous projects, we should not be daunted by comparison with the vast amounts of cash and technology floating around America. This wealth is not surprising given the population of that country, available capital, and technological expertise. In fact AFSAAP, under the forwardlooking leadership of Tanya Lyons and her executives, has already splendidly achieved the digitisation of our own journal, and various other resources, as well as providing financial resources to seed another project, though that has yet to deliver. Even in the U.S., surprising is the very limited number of universities and African studies centres able to successfully coordinate resources and produce successful digital projects. In part, this has been due to the sharp competition that lies at the heart of the American system, and which makes it relatively difficult to bring about genuine cooperation. On the other hand, MSU certainly brokered some fine inter-university partnerships. For example, between MSU, Harvard, historically black colleges, UCAD in Senegal, and universities in Malawi, Mali, Ghana South Africa, and so on. Many of these digital projects are represented on the website of the African Online Digital Library (https://www.aodl.org) that has developed over the last two decades. Some of the most interesting and useful in terms of research and education include Tolerance in Islam in West Africa, Overcoming Apartheid, Community Video Education Trust, and Slave Biographies. These and a related project, the Archive of Malian Photography (http://amp.matrix.msu.edu), have built in local capacitisation and avoided removing any materials from Africa. This is not to say that things always go smoothly. The competition between Africanists from different American universities was evident at a conference held on digital slave trade studies at MSU a few years ago, when scholars at MSU and Emory University each hoped to corral future digital projects inside their own centres. Yet positive and negative electrodes produce light.

One useful lesson that Africanists in Australasia can take away is a need for cooperation, trust and coordination in research and projects. Easier said than done, and I am mindful that in the Australian situation of cramped research funding, university rivalry is just as apparent. This is where 
organisations such as AFSAAP come into play. AFSAAP has a vital role to play in coordinating, not only its own members (which include students, academics, NGOs, diplomats etc.), but also other groups now emerging, inspiring and keeping us in touch with each other and offering a forum both in terms of the annual conference and The Australasian Review of African Studies to exchange ideas, to consummate projects, and work up new ones.

\section{Foundations: Demography, New African Communities, and Funding}

We have a very fine demographer of Africa in our midst, David Lucas, which reminds me of the material foundations for a flourishing African studies superstructure. The United States has a huge population of 329 million people, together with a substantial, if relatively declining African American component that tends to provide an element of community and intellectual engagement with Africa. There can be rival academic empires and sometimes tensions between African Americans and 'American Africans', as Ali Mazrui used to say. But it is clear to me that Australian African Studies now has a substantial human base for growth, in the first place from our growing African Australian community.

It is becoming very evident that immigrant communities in Australia from African countries, most notably South Sudan but in fact from many nations, are now well established and we can expect a modest increase of interest from them in the study of their homelands as time goes by. How deep this will be is uncertain, but the examples from the twentieth century of, say, Greeks in Melbourne, Vietnamese in Sydney, or Italians in Western Australia (which led to what is probably the largest constellation of Italian studies in Australia at UWA) is something to ponder. I would like to draw attention to the rather inevitable transition from American Africans to African Americans; it is likely a similar thing will happen here and I wonder whether we shouldn't be doing more to try and garner 'the African' component in the African Australian experience. It is wonderful to see, for instance, South Sudanese excelling in Australian Rules football, but how might we also encourage immigrants and their children to study Africa? This is not always done very successfully in either Europe or America and it is not easy.

The American ASA has a range of different categories of affiliates including country-focused affiliates such as the Ghana Studies and Nigeria Studies associations, others such as the ASA Women's Caucus, the ASA Outreach Council, Islam in African Studies Group, Lusophone African Studies Organization. Over the years, some bodies have fallen away whilst new ones arise and affiliate (such as, more recently, the North American Association of Scholars on Cameroon), but the model is interesting not least 
in the way ASA allows a degree of affiliate flexibility. Some African communities in Australia are quite small, but those that have grown substantially in the last two decades, such as from the Horn of Africa, appear to offer greater potential for a range of African Studies connections. I know AFSAAP already has been doing a lot in this regard. Perhaps there is scope for AFSAAP to broaden and deepen its affiliates.

\section{Foundations: Libraries and digital resources}

This is an area where Australia really needs more investment. Latrobe, UWA and Melbourne invested heavily in library research materials in the eighties and nineties, laying the ground work for more postgraduate theses. I have not seen much evidence of similar investment in the last two decades, but perhaps some of you have positive stories to share? Administrators like to imagine in their administrative fantasies that all you need is a digital library, and there is a certain logic to this, but such cramped policy just does not work when researching Africa where in most countries the largest percentage of academic publications are still in print. The result can be studying a very diverse continent chiefly from publications not from Africa, but from the North.

This is changing with more digital publishing in many African countries, but a balance and depth is needed to support higher quality research. Australia made the decision to collect heavily on Southeast Asia at the National library and ANU, and before that on South Asia and East Asia, so there is a capacity but it needs active pushing by academics to get librarians back in the groove. In the meantime, budget cuts and lack of lateral thinking will probably mean minimalist research collections. The situation in the U.S. is just so far ahead, even of Europe, and yet even there, only a small number of research universities with very large African studies budgets, notably Northwestern, MSU, UCLA, Harvard and a few others are building highlevel collections. Some previously leading universities have pulled back their involvement in African studies, notably Yale, although there are rumours of a return to the fray.

In Europe, it is more patchy. Oxford and Cambridge, together with the British Library and Birmingham, continue to muster impressive collections in some regions of Africa, and there have been important new developments such as the Sudan Archive at Durham. On the other hand, in some countries with a colonial past in Africa, there has been a degree of slippage, such as in Belgium, and to an extent Britain. Germany retains some substantial pockets of interest but even at major centres such as Hamburg and Frankfurt, library collections on Africa can be quite limited, locked as they are in a strange sort 
of federal arrangement. Individual research institutes such as the Nordic African Studies Centre in Uppsala, Sweden, and the BAB in Basel, Switzerland have fine collections, if specialised, the former focusing more on contemporary Africa, the latter chiefly on Namibia. There might be a lesson here for Australian and New Zealand institutions of higher education to deploy limited budgets in cooperative, coordinated ways to develop specialised collections on particular African countries at different universities.

\section{Foundations: Publishing and new technology}

This is a strong point of both American and European African studies and a weakness for us here. And yet, Africanists in Australia have been able to leverage some Australian university presses quite well. I am thinking of publications by Norman Etherington, Derek Schreuder, and others in previous decades. I have noticed happily from afar that some of you, such as Tanya Lyons, Tony Binns, David Mickler and Gareth Griffiths have continued to publish books in mainstream publishers from the North. Most of these works are published in the social sciences and humanities. Perhaps there are ways of leveraging commercial or independent publishers here in other fields such as comparative fine arts and applied sciences such as agriculture. Another suggestion would be to try and collectively work on books series.

New technology offers possibilities of extending our knowledge more widely into society. Digital open access publishing is always an option but is not always a panacea in academia. Streaming joint conference sessions with African universities have been a success lately, as have conference podcasts. ASFSAAP's YouTube production with interviews from the 2016 conference in Perth was a step in the right direction. Underpinning successful digital outreach, such as the Africa Past and Present podcast with which I have been associated for the last decade, is technical knowhow; at MSU this takes the form of a dedicated, specialised digital humanities unit, Matrix. Not many U.S. universities have bothered to develop this kind of capacity, but it has repaid itself many times over with substantial grants and an extensive digital publication record. Outlays need not be massive and provided there are skilled technicians and academics who pick up some skills, then quite a lot can be done on a shoestring budget.

\section{Foundations: Centres, institutes, associated organisations}

It is worth considering the organisational aspects of African Studies. In Europe, there is considerable diversity, country by country. ECAS has been 
a wonderful success story, not just in large attendances, but also in rotating conference venues among different European cities, from Lisbon, London and Leipzig to Paris, Uppsala and Edinburgh, as well as developing a rich and varied program. Making the conference biennial has allowed more time to organise, something appreciated in 1999 when Cherry Gertzel and I spent an entire year building the AFSAAP conference. Advance conference scheduling will help us better plan. Europe has the advantage of being close to some African countries. Australian Africanists sometimes have been able to exploit relative geographic proximity with regard to Southern and Eastern Africa. One suggestion here would be to invest more in the Africa-Asia connection, particularly with regard to China and India. There are all kinds of China-Africa institutes and networks. In this regard, a spinoff might be book series or journal special issues focused on Asia and Africa together.

The most effective avenue of developing African Studies is, however, probably dedicated centres. The recent establishment of AfREC at UWA is the first such centre in our region since the highly successful African Research Institute formed at La Trobe University in the 1970s under the able leadership of David Dorward, which later fell victim to bureaucratic short sightedness. AfREC is an example of the successful application of the cooperative spirit. David Mickler and his team has already, in the first year of the new Centre, built impressive contacts with African universities. Long term funding and the distractions of the corporate world may still be obstacles, but surely there is cause here for guarded optimism-and a 'model' that might be replicated in other universities.

\section{Future directions}

Which way should we turn in the future? I would always caution, in the long-run, against downplaying "the African" in favour simply of "ethnic studies", of lurching too far towards a singular focus on "African Australian" studies, if I can put it that way, delicately. For that dimension of Australian life will be picked up, as it already is being, by the social sciences. A judicious balance between the two would be in the interests of both approaches and guard against some of the weaknesses I have seen in the U.S. I would like to see always the warmest welcoming of African Australian themes and African Australians, as well as Australian Africans, within AFSAAP, at the same time that we strengthen our understanding of the continent and our direct contacts there. They are complementary. And I anticipate the second (and third) generations of African Australians will return with gusto to embrace the study of Africa.

Let me finish by encouraging more Africans to join AFSAAP Executive! 